\title{
THE ISLAMIC ETHICS OF ABORTION IN THE TRADITIONAL ISLAMIC SOURCES
}

Before inexpensive, effective birth control was readily available, sexual intercourse generally led to reproduction. Large numbers of living children (as long as the incidence of twins and other multiple births was kept to a minimum) were generally desirable in settled, agricultural societies. In nomadic societies, such as those of pre-Islamic Arabia, unwanted children could be a serious burden on the limited food resources of the tribe. This was especially true in the case of girl children. Consequently, preIslamic Arabians often buried unwanted children alive as a means of reducing pressure on their resources.

With the advent of Islam and its new morally-based social order, old problems about resource allocation still had to be addressed, but in light of the new religious order. Killing a human being without just cause was seen to be wrong, so how could killing one's own children be considered acceptable? Nevertheless, having large numbers of unwanted children was still burdensome, so that the solution of 'azl, or coitus interruptus, was accepted as a birth control method among Muslims.

In the Qur'anic worldview, the birth of children created a series of obligations for the parents as well as for relatives of varying degrees. In the case where the mother was the slave of the father, it also created new obligations for the father toward the mother. In such situations there would be many people who could have a possible economic or social motivation to prevent a potential child from being born. Additionally, women were well aware of the dangers of dying in childbirth as well as the physical and mental strain accompanying each additional child.

The earliest Islamic sources, the Qur'ān, the hadith of the Prophet, and the earliest legal scholars, do not discuss the question of abortion in the same sense that it is understood in the West, that of a pregnant woman deliberately seeking to terminate a pregnancy before the birth of a child. These sources do, however, attempt to deal with the problems of unwanted children and of the ethical issues these problems raise. In general, these sources frown upon the killing of children, either after they are born or while they are in the fetal stages.

We do find in some of the Islamic sources that a distinction is made between the death of a fetus less than 120 days old and a fetus older than that age based on the traditions of the Prophet. Madith of the Prophet and legal rulings by the scholars on the subjects of killing and burial seem to 
indicate that a fetus before the gestational age of 120 days is not a Muslim or even a person, although the fetus is treated as a "potential" person in some sense. After 120 days, however, a fetus is a Muslim person and should be treated accordingly, although the punishment for killing an older fetus still differs from that which would be received for killing a person who had lived and breathed. "Treated accordingly" means buried in a Muslim cemetery and avenged for in case of death. A fetus can, according to some accounts, inherit, and killing a fetus of more than 120 days is an act punishable by God and Muslim law.

The question of the ethics of abortion in Islam can only be answered by beginning with a close examination of the Qur'ann, the source of all truth, and the Sunna, the living example of the Prophet. Only once a study of these fonts is complete may we begin to look in other waters. In this article I will cover the Qur'anic discussion of topics related to abortion ( $\ddot{j h} \bar{a} d$ ) and ethics (even though Allah did not make a definitive statement in this matter); I will also survey the Prophetic examples on these questions, as well as some legal interpretations. This is only a short sample of the legal rulings available, focusing on the ethical implications in the limited space available. Munawar Ahmed Anees gives a broader summary of scholars and their opinions on the admissibility of abortion, ${ }^{1}$ but he concentrates his discussion on the legal implications more than on the ethical ones of this act.

It should be remembered that the Islamic understanding of abortion in these texts is not related to the contemporary debate in the U.S. and in other countries. The barely concealed subtext of this modern debate is the question of sex out of wedlock and the consequences in this life for such an act. This aspect of the problem is not present in any of the sources, because the hadd punishment for sex out of wedlock is either death or lashing, depending on the marital status of those involved.

\section{Undesirability of killing one's children}

Allah has made clear that killing people is an ethical wrong, as their lives are made sacred by Allah's having created them. "And do not kill anyone whom Allah has made sacred, except for a just cause... " (Qur’ān $17: 33)^{2}$ This applies to killing anyone at all-killing one's children is especially forbidden by Allah. "They are lost indeed who kill their children

\footnotetext{
1 Munawar Ahmad Anees, Islam and Biologica) Futures (London: Mansell Publishing, 1989).

2 Unless otherwise specified, all translations are from M.H. Shakir, Holy Qur'an (Elmhurst, NY: Tahrike Tarsile Qur'ān, 1983). In this case, I bave translated harrama as "sacred" but it could also be rendered "protected".
} 
foolishly without knowledge, and forbid what Allah has given to them, forging a lie against Allah; they have indeed gone astray, and they are not the followers of the right course." (Qur'ān 6:140) Believers are instructed specifically not to kill their children for fear that they will be unable to provide for them,

... and do not slay your children for (fear of) poverty-We provide for you and for them-and do not draw nigh to indecencies, those of them which are apparent and those which are concealed, and do not kill the soul which Allah has made sacred except for the requirements of justice; this he has enjoined you with that you may understand. (Qur'ān 6:151)

Some pre-Islamic societies were reported to kill their children on altars and sacrifice them to gods. Allah reveals in the Qur'ann that it is proper to be willing to obey your Lord to such a degree but that this is a wrong thing to do. ${ }^{3}$ Ibrāhim, the father of a much-awaited son, Ismā'ill, sees in a vision that he should offer the boy in sacrifice. After he places Ismã îl on the altar, Ibrāhim is just about to cut the child's throat when Allah stops him with the words, "You have already fulfilled your vision!" and rewards the family. With this story in mind, all Qur'anic verses instructing people not to kill their children should be interpreted to mean: 'You should be willing, in obedience to $\mathrm{Me}$, to kill your children as Ibrāhim was, but this would never be commanded and thus you should never do it.' This is relevant to the question of induced abortion in that it shows how Allah discourages people from killing their children. Again, while there is no explicit mention of abortion in the text, similar situations such as this provide precepts upon which an ethics of abortion may be based.

According to 'Abdullāh $b$. Mas' $\bar{u} d$, the Prophet held the killing of one's children for fear of poverty to be the second gravest sin:

I asked Allah's messenger (may peace be upon him): Which sin is the gravest with Allah? He (the Holy Prophet) replied: That you associate a partner with Allah, while it is Him Who has created you. He (the reporter) said: I told him (the Holy Prophet): Verily it is indeed grave. He (the reporter) said: I asked him what the next (gravest sin) was. He (the Holy Prophet) replied: That you kill your child out of fear that he shall join you in food.... ${ }^{4}$

3 See, for instance, Qur'an 37:99-113.

4 Unless otherwise noted, all hadith translations are from a/-Bayan CD-rom (Heliopolis, Egypt: Sakhr publications, 1996). This hadith is compiled on this CD-rom by al-Bukhārin in the book of Tafsir, Muslim in the book on Faith, al-Tirmidhi in the Book of Tafsir, al-Nisāi in the book on Blood is Inviolable, Abū Däwūd in the book of Divorce. See also Ahmad b. Hanbal, Mfusnad (Beirut: Al-Maktab al-Islāmi, 1969), vol. 1, 380. 
This hadith points to the essentially unjust and wrong nature of killing in general, especially killing one's own children. As I will demonstrate in the following section, fetuses before 120 days are not "souls" or children and would not be included in this injunction. But fetuses over 120 days are Muslim persons and should be treated as such. There may still be a just reason for killing one, but without a reason specified by Allah as acceptable, killing them is a grave wrong.

Burying one's children or otherwise killing them for the reasons of their sex, as was a pre-Islamic practice in Arabia and lamentably is continued in some patriarchal societies in the modern times, is evil, according to Allah's word:

And when a daughter is announced to one of them his face becomes black and he is full of wrath. He hides himself from the people because of the evil of that which is announced to him. Shall he keep it with disgrace or bury it (alive) in the dust? Now surely evil is what they judge. (Qur'ān 16:58-59)

This act of female infanticide is evil and also unjust, as Allah implies in another surah, "And when the female infant buried alive is asked for what sin she was killed." (Qur'ān 81:8-9) Since Allah stated that people are only to be killed for just reasons, and since sin is not attributed in Islam to individuals before the age of reason, this child could not have sinned and was therefore killed unjustly.

\section{Establishment of a time period (120 days) before which a fetus is not a person}

Allah states clearly in the Qur'ann the method of human development in the womb. "O people! if you are in doubt about the raising, then surely We created you from dust, then a small seed, then from a clot, then from a lump of flesh, complete in make and incomplete... "Qur'ān 22:5) Here it is clear that human existence is not human until the lump of flesh stage is completed, since the verse addresses people and describes what people are created from in succession before they become people. Similarly if I make a batter out of flour and then knead it into dough, it is only in its final form after I bake it that it is bread. A similar account in several other places in the Qur'ān ${ }^{5}$ makes it incontrovertible that Allah creates humans in stages and that before the final stage they are not humans. Anees notes this as well:

5 Including Qur'ān 23:12-14, 35:11, 39:6, 71:14, 75:37-38, and 77:20-21. 
It is obvious that the Muslim juristic appraisal of the legality of induced abortion hinges on one and only one determinant: transformation from a 'biological' being (may be taken as an equivalent of the animal stage of development) to a human being. This transmutation is brought about when the spirit is infused into that biological being. 6

Further, Anees shows that scholars such as al-Qurțubī, al-Ghazālī, al-Tūsì and al-Hillī in the medieval period and Shalțūt, al-Zarqā, Muhammad Asad, and Bahishti in the modern period have interpreted this surah in this way. The language in this surah is also echoed in a tradition of the Prophet.

Anas b. Mālik reported, Allah's messenger (may peace be upon him) said: Allah, the Exalted and Glorious, has appointed an angel as caretaker of the womb, and he would say: My Lord, it is now a drop of semen; my Lord, it is now a clot of blood, my Lord, it has now become a lump of flesh, and when Allah decides to give it a final shape, the angel says: My Lord, would it be male or female or would he be an evil or a good person? What about his livelihood and his age. And it is all written as he is in the womb of his mother. ${ }^{7}$

Once again, the fetus is just a drop or a clot or a lump until Allah decides to give it its final shape, and at that time its future is established by Allah. Finally, this same language is used in a hadith which states that each of the first three stages represents 40 days.

'Abdullāh said that the Prophet of God (may peace and blessings be upon him) said that the sperm is in the womb for forty days without its condition changing. When it has passed these forty days it becomes a clot, then in that manner it becomes a bigger thing likewise, and when Allah wants to complete its creation, He sends an angel. He tells the angel that which He commands for it: for example, male or female, unhappy or joyful, short or tall, weak or strong, and he makes the person healthy or infirm. He (the Prophet) said that he (the angel) writes all of this down...."8

So the Qur'anic description of creation within the womb is confirmed by hadith to fall into two major stages, marked by the line of 120 days.

Anees, Biological Futures, 177.

7 Sakhr Publications, al-Bayān; compiled by al-Bukhāri in the book on Menstruation, and Muslim in the Book on Destiny. See also Ahmad b. Hanbal, Mfusnad, vol. 3, 116 and 148.

8 Ahmad b. Hanbal, Musnad, vol. 1, 374-75. 


\title{
Punishment for causing a pregnant woman to miscarry is diya, not hadd
}

The earliest legal sources do not address the question of a woman voluntarily seeking abortion, but important precepts are established in discussion of forced miscarriages. If someone causes a pregnant Muslim woman to have a miscarriage, that person must pay an indemnity to the woman's family but will not be submitted to the hadd punishment for taking life. This is explained in a hadith of the Prophet:

\begin{abstract}
Al-Mughīrah b. Shu'bah, may Allah be pleased with him, reported: a woman struck her pregnant co-wife with a tentpole and she killed her. One of them belonged to the tribe of Lihian. Allah's messenger (may peace be upon him) made the relatives of the murderer responsible for the payment of blood-money on her behalf, and fixed a slave or a female slave as the indemnity for what was in her womb. One of the persons amongst the relatives of the murderer said: "Should we pay indemnity for one who neither ate, nor drank, nor made any noise, who was just like a nonentity?" Thereupon Allah's messenger (may peace and blessings be upon him) remarked: "He speaks rhymed phrases like the people of the desert." He did impose indemnity upon them. ${ }^{9}$
\end{abstract}

Other hadith echo this incident in slightly different terms.

The early legal scholars necessarily had something to say about this question as well. In the Mudawwanah, the book of Blood-Money, Sahnūn (d. 855) holds that Mālik wanted whoever caused a pregnant woman to miscarry to pay an indemnity. ${ }^{10}$ The length of the woman's pregnancy to that point was not included as a relevant consideration, and this rule applied whether the offender was intentionally or not intentionally ending the pregnancy, as long as the offender was aware that the woman was pregnant. Also according to Sahnūn, Mālik held that even if the father of the child should seek to end his wife's or slave-girl's pregnancy, he and his kin-group are only responsible for the indemnity. ${ }^{11}$ In other words, the Mudawwanah considers the idea that a man would try to abort a fetus, but it does not consider that a woman would deliberately try to end

9 Sakhr Publications, al-Bayän; compiled by al-Bukhāri in the book on Indemnities, Muslim in the book on a/-Qasamah, al-Tirmidhi in the book on Indemnities, al-Nisāi in the book on $a /$. Qasamah, Abū Dāwūd in the book on Indemnities, and Ibn Majjah in the book on Indemnities. See also Ahmad b. Hanbal, Musnad, vol, 4, 244. Hadith are arranged by the collectors in a variety of ways, and these reports may contain information on more than one topic but may only be indexed in one place. It is for this reason that information on abortion is sought in chapters such as that on indemnity.

10 Sahnūn b. Sa'id, al-Mudawwanah al-Kubră (Beirut: Dār al-Kitāb al-Ilmiyya, 1994), vol. 4, 230-33.

i1 Interestingly, however, the father would also get a share in this indemnity. 
her own pregnancy. ${ }^{12}$ Again, the requirement on indemnity shows that forcing a miscarriage is wrong, even if it is not murder. Further, the intention to cause miscarriage is not the question, as long as the offender knew of the pregnancy.

Ibn Hazm (d. 1064) in the Muhallah takes a slightly different view. It should be remembered that this medical man lived after the great advances in science and medicine of the ninth century of the common Era-abortion would have been a good deal safer for the mother. Ibn Hazm also lived most of his young life in close association with women, as he states in his Tawg al-Hamamah, and it is perhaps due to experience with seeing the women deal with unwanted pregnancies that his analysis reflects the possibility of the woman's own choice in this matter. The mother who intentionally tries to miscarry a fetus less than 120 days of gestation pays a penance, according to Ibn Hazm, as if she had broken a vow or some such, but not an indemnity. If someone else causes a woman to abort before the fetus has reached 120 days gestation, this person would be liable for an indemnity. In the case of a fetus that is of more than 120 days gestation, anyone who causes it to abort is liable for an indemnity. ${ }^{13} \mathrm{Ibn}$ Hazm is committed to the concept that a fetus of more than 120 days gestation is a live person-he judges it to be essential that such a fetus be saved by caesarean section if the mother is dead, to avoid burying a live fetus with a dead mother, which would be wrong. ${ }^{14}$

Again 350 years after Ibn Hazm, the question of abortion has acquired new legal dimensions, if not new ethical considerations. Ahmad b. Naqib al-Missī (d. 1368) considered in the Reliance of the Traveller that if a baby was born dead, and was of greater than 120 days gestation, it was washed before burial; even though the fetus was not a living Muslim, it was still a Muslim and would need to be treated as any other. But if the fetus was of fewer that 120 days, it was simply buried. The implication is that a fetus of fewer than 120 days was not a person at all, which is the same argument that seemed to be underlying Ibn Hazm's rules. ${ }^{15}$ Al-Mișrī

\footnotetext{
12 It should be remembered that striking or otherwise injuring the body cavity of a pregnant person in this period (or even until very recently) was an almost certain death sentence for the victim. In the even of an incomplete abortion, an emergency Dilation and Curettage would have been impossible, and gangrene would have very likely set in. I believe it is for that reason that early scholars such as Sahnūn would not have needed to consider that the mother would strike herself in the belly in such a way as to abort. This would be tantamount to suicide on her part, which is covered elsewhere.

13 (Alì b. Aḥmad Ibn Hazm, a/-Muhallah, trans. Fouad Muhammad Ayad (Texoma, TX: Islamic Mosque at Texoma, 1985), 278-79.

14 Ibid., 99.

15 A hmad b. Naqïb al-Mişri, Reliance of the Traveller, trans. Noah Ha Mim Keller (Evanston, IL: Sunna Books, 1991), 236 (section g-4.21). This is a work of Shăfi' $\bar{i}$ jurisprudence, which has been commented upon by Umar Barakat (d. after 1890) and by Noah Ha Mim Keller.
} 
does not make the same distinctions as Ibn Hazm did about indemnity (diya). He instead offers the ruling, similar to that of Mãlik, that a diya is due from whomever causes the miscarriage. The ruling is not divided into any sort of categories according to the gestational age of the fetus, and neither parent's possible involvement in the act is mentioned. ${ }^{16}$

In summary, Allah has made it clear, by way of the Qur'ann, that it is wrong to take a life which Allah has protected. Allah also says in the Qur'ann that a fetus in a womb is not a human person until a specified period has passed. The Prophet's example adds that the period specified is 120 days of gestation, after which the fetus is treated as a Muslim, although not in exactly the same way as a living Muslim, since hadd punishments are not imposed if a woman is forced to miscarry and the fetus dies. The legal scholars continue the argument that it is wrong to cause a pregnant woman to miscarry, and that this wrong should be punished, though they differ in slight detail as to how.

Finally, it can be said that although abortion in the first 120 days of gestation is morally wrong in Islamic law, it is not considered to be murder or even killing. Rather, abortion in this early period would fall into the categories of bodily injury or breaking of an oath, both of which require some type of penance. The killing of one's children, however, is categorized as one of the gravest of sins in both Qur'ān and hadith. The question remains, then, how to categorize abortion of a fetus older than 120 days; it appears that such an abortion comes perilously close to the sin of killing children, and thus requires clear arguments of necessity, such as saving the life of the mother. 